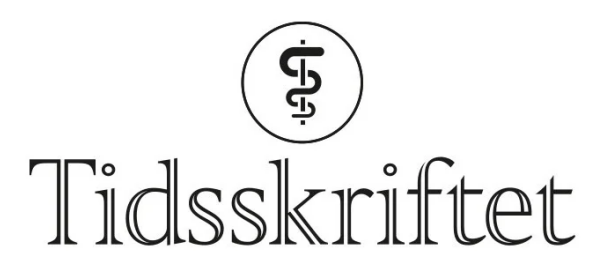

DEN NORSKE LEGEFORENING

\title{
Antibiotikaprofylakse eller infeksjonsprofylakse?
}

SPRÅKSPALTEN

ERLEND HEM

erlend.hem@medisin.uio.no

Erlend Hem er instituttsjef ved Legeforskningsinstituttet, professor ved Universitetet i Oslo og leder av Gruppe for norsk medisinsk fagspråk.

\section{Antibiotika kan forebygge infeksjoner. Hvilken betegnelse bør man bruke om slik profylaktisk behandling?}

Profylakse handler om å forebygge noe (1). Antibiotikaprofylakse er forebygging med antibiotika. Noen kan mene at dette ordet ikke er logisk, fordi det kan gi inntrykk av at det er antibiotika som forebygges. Bør det kanskje heller kalles infeksjonsprofylakse, slik som tromboseprofylakse, hvor det er henholdsvis infeksjon og trombose som forebygges? Men slik er det ikke. Både antibiotikaprofylakse og tromboseprofylakse er etablerte og akseptable uttrykk på norsk.

\section{Språket er fleksibelt}

Språket vårt er mer fleksibelt enn mange tenker seg. Det er ikke noe i veien for å sette sammen substantiver på ulike måter - det gjør vi stadig vekk. Sammensetninger kan følge ulike mønstre med samme etterledd. «Forholdet mellom leddene i en sammensetning kan være av det mangfoldigste slag, og det blir vår viten om verden og hvordan den er innrettet, som bestemmer hvilken betydning sammensetningen skal ha», skriver Finn-Erik Vinje (므).

Fra dagliglivet kjenner vi for eksempel kjøttpølse og kyllingpølse, som indikerer hva pølsene er laget av, mens familiepølse og jegerpølse åpenbart er dannet på en annen måte. Når vi påtreffer ordet selvvask på en bensinstasjon, kan man tenke seg to muligheter: Her kan man enten vaske bilen selv eller man kan vaske seg selv, men det er selvsagt det første som er riktig. Vi omgir oss med en rekke sammensetninger som teoretisk sett er tvetydige, men som i praksis er entydige (므). En ferjekø kan bety en k $\emptyset$ av ferjer, men mer sannsynlig er at det er snakk om en kø av kjøretøyer som ønsker å kjøre om bord i ferja. På samme vis betyr

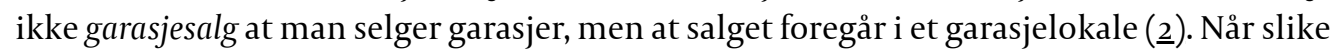
sammensetninger nesten aldri forårsaker misforståelser, men tolkes etter intensjonen, er det fordi konteksten legger til rette for den intenderte betydningen (3). 
En vanlig feil i moderne norsk er for øvrig tendensen til å oppløse sammensetninger, det vil si at man skriver antibiotika profylakse og trombose profylakse i to ord i stedet for ett. Dette kalles særskriving og skyldes engelsk påvirkning (3).

\section{Determinative sammensetninger}

Forfatterne av boka Norsk referansegrammatikk viser hvor fleksibelt norsk er i forbindelse med ordsammensetninger (4):

tømmerhytte: hytte av tømmer (materiale)

feriehytte: hytte for ferie (hensikt)

fjellhytte: hytte på fjellet (sted)

sommerhytte: hytte for sommerbruk (tid for bruk)

selvbetjeningshytte: hytte med selvbetjening (måte man bruker hytta på)

Disse eksemplene er såkalte determinative sammensetninger, der etterleddet gir hovedbetydningen og forleddet avgrenser eller modifiserer betydningen til etterleddet (4.).

Konklusjonen er altså at både antibiotikaprofylakse og infeksjonsprofylakse er akseptable ordkonstruksjoner på norsk. Ordbruken er innarbeidet gjennom mange år og skaper neppe misforståelser.

\section{LITTERATUR}

1. Profylakse. I: Det norske akademis ordbok. https://naob.no/ordbok/profylakse Lest 20.12.2020.

2. Vinje F-E. Sjærlighet og sjøttkaker: språklige gleder og gremmelser. Oslo: Schibsted, 2012: 26.

3. Vinje F-E. Norske ord i hus og hytte: om språkets byggeklosser. Oslo:Vidarforlaget, 2019:115-8.

4. Faarlund JT, Lie S, Vannebo KI. Norsk referansegrammatikk. Oslo: Universitetsforlaget, 1997: 63.

Publisert: 14. februar 2022. Tidsskr Nor Legeforen. DOI: 10.4045/tidsskr.21.00o6

(C) Tidsskrift for Den norske legeforening 2023. Lastet ned fra tidsskriftet.no 26. april 2023. 